NBER WORKING PAPER SERIES

ASBESTOS AND THE FUTURE OF MASS TORTS

Michelle J. White

Working Paper 10308

http://www.nber.org/papers/w10308

NATIONAL BUREAU OF ECONOMIC RESEARCH

1050 Massachusetts Avenue

Cambridge, MA 02138

February 2004

The views expressed herein are those of the authors and not necessarily those of the National Bureau of Economic Research.

(C)2004 by Michelle J. White. All rights reserved. Short sections of text, not to exceed two paragraphs, may be quoted without explicit permission provided that full credit, including (C) notice, is given to the source. 
Asbestos and the Future of Mass Torts

Michelle J. White

NBER Working Paper No. 10308

February 2004

JEL No. K13, K41, L5, I18

\begin{abstract}
Asbestos was once referred to as a "miracle mineral" for its ability to withstand heat and it was used in thousands of products. But exposure to asbestos causes cancer and other diseases. As of the beginning of 2001, 600,000 individuals had filed lawsuits for asbestos-related diseases against more than 6,000 defendants. 85 firms have filed for bankruptcy due to asbestos liabilities and several insurers have failed or are in financial distress. More than $\$ 54$ billion has been spent on the litigation - higher than any other mass tort. Estimates of the eventual cost of asbestos litigation range from \$200 to \$265 billion.

The paper examines the history of asbestos regulation and asbestos liability and argues that it was liability rather than regulation that eventually caused producers to eliminate asbestos from most products by the late 1970s. But despite the disappearance of asbestos products from the marketplace, asbestos litigation continued to grow. Plaintiffs' lawyers used forum-shopping to select the most favorable state courts, developed new techniques for mass processing of claims, and substituted new defendants when old ones went bankrupt. Because representing asbestos victims was extremely profitable, lawyers had an incentive to seek out large numbers of additional plaintiffs, including many claimants who were not harmed by asbestos exposure.

The paper contrasts asbestos litigation to other mass torts involving personal injury and concludes that asbestos was unique in a number of ways, so that future mass torts are unlikely to be as big. However new legal innovations developed for asbestos are likely to make future mass torts larger and more expensive. I explore two mechanisms-- bankruptcies and class action settlements--that the legal system has developed to resolve mass torts and show that neither has worked for asbestos litigation. The first, bankruptcy by individual asbestos defendants, exacerbates the litigation by spreading it to non-bankrupt defendants. The second, a class action settlement, is impractical for asbestos litigation because of the large number of defendants. As a result, Congressional legislation is needed and the paper discusses the compensation fund approach that Congress is currently considering.
\end{abstract}

Michelle J. White

Department of Economics

University of California, San Diego

La Jolla, CA 92093-0508

and NBER

miwhite@ucsd.edu 


\title{
Asbestos and the Future of Mass Torts
}

\author{
Michelle J. White ${ }^{1}$
}

Legal claims for injuries from asbestos involve more plaintiffs, more defendants, and higher costs than any other type of personal injury litigation in U.S. history. As of the beginning of 2001, 600,000 individuals had filed lawsuits against more than 6,000 defendants and the total amount that defendants and insurers had spent on resolving claims —including all legal costs—was estimated to be $\$ 54$ billion (Carroll et al., 2002). . Eighty-five corporations have filed for bankruptcy due to asbestos liabilities and several insurance companies have either failed or are in financial distress (White, 2002b). Estimates of the total number of people who will eventually file claims range from 1.1 million to 3.0 million and estimates of the eventual cost of asbestos litigation range from $\$ 200$ to $\$ 265$ billion (Carroll et al., 2002).

Asbestos was once referred to as the "miracle mineral" for its ability to withstand heat. It was heavily used as a fireproofing and insulating material in ships, buildings and consumer products, including wallboard, roofing, flooring, cement, insulation, drinking water pipes, automobiles, clothing, paper, hair dryers, garden products, home appliances, artificial firelogs, and children's toys. Estimates of the number of Americans exposed to asbestos range from 27 million to 100 million (Biggs et al, 2001).

Breathing asbestos fibers-which can be microscopic - causes a variety of diseases. Two of these diseases, asbestosis and mesothelioma, are uniquely associated with asbestos exposure. Asbestosis is scarring of the lungs that reduces breathing capacity; it can range from non-disabling to fatal. Mesothelioma is cancer of the pleural lining around the chest and abdomen and is quickly fatal. Other asbestos diseases such as lung cancer, gastrointestinal cancer, and pleural plaque (thickening of the pleural lining that is non-disabling) can be caused either by asbestos exposure or by other factors including smoking. Asbestos diseases have a long latency period: 20 to 40 years usually elapse

\footnotetext{
${ }^{1}$ I am grateful to the National Science Foundation for research support under grant \#0212444 and to Eli Berman, Roger Gordon, Jim Hines, Andrei Shliefer, Tim Taylor, and Michael Waldman for very helpful comments.
} 
between exposure and diagnosis. Longer and heavier exposure to asbestos increases the probability of developing asbestos diseases, but they can also occur in people who had only limited exposure (Carroll et al., 2002). A famous study of 370 insulation workers who were union members in 1942 illustrates the grim effects of asbestos: between 1963 and 1968, 113 of the workers died when 60 deaths would normally be expected. The deaths included 28 from lung cancer (2.5 would be normal) and 8 from gastrointestinal cancer ( 2 would be normal), plus 15 from asbestosis and 13 from mesothelioma ( 0 would be normal) (Brodeur, 1973, p. 29). Asbestos can also cause disease in workers' family members and bystanders, who are exposed to asbestos dust on workers' clothes or in the environment.

In this article, I first examine why regulation failed to prevent asbestos from becoming so widely used and how asbestos litigation widened from a trickle into a

torrent. I also consider other countries' experience with asbestos and whether regulation or liability is more effective in deterring production of dangerous products. The article then asks how asbestos litigation differs from other mass torts: does asbestos litigation represent a "perfect storm" where many factors came together with disastrous results, or does it represent a path that is likely to be followed by other mass torts involving personal injury? Various ways in which the asbestos crisis might be resolved are considered, including bankruptcy, a class action settlement, legislation now pending in Congress to establish a national asbestos compensation fund, and an alternative approach that would centralize asbestos lawsuits in a single federal court.

\section{Liability versus Regulation of Asbestos Exposure}

\section{The failure of regulation}

As early as the 1920s, physicians recognized that exposure to asbestos caused disease and asbestosis was named and described in British medical journals. Around the same time, insurance companies in the U.S. and Canada stopped selling life insurance to asbestos workers. In 1931, the British government began regulating workplace safety in the asbestos industry, monitoring workers for asbestosis, and providing worker's compensation to those who were disabled by it (Tweedale, 2000, p. 21). Safer 
substitutes for many uses of asbestos were known as early as the 1930s (Castleman, 1996, ch. 6). Nonetheless, U.S. consumption of asbestos increased from 100,000 metric tons in 1932 to 700,000 metric tons in 1951 and peaked at 750,000 metric tons in 1974 . Thereafter, usage declined to about 25,000 metric tons in 1994 (Castleman, 1996, p. 788). That asbestos was so widely used from the 1950s to the 1980s suggests that multiple regulatory systems failed, including workers' compensation, workplace safety regulation, product safety regulation, and liability law.

In the United States, many states' workers' compensation systems began to cover occupational diseases starting in the 1930s, but few workers with asbestos-related diseases received compensation. ${ }^{2}$ In response to lobbying by asbestos producers and insurers, asbestos-related claims were subject to highly restrictive eligibility rules. Asbestos diseases develop slowly and symptoms are easily mistaken for other diseases, so that workers often left their jobs without knowing that they had asbestos disease and this often meant that they did not quality for compensation. Indeed, asbestos producers such as Johns-Manville conducted physical examinations of their workers, but did not inform them if they had asbestosis in order to keep down the number of compensation claims. Other workers were ineligible because of short statutes of limitations for filing claims (Castleman, 1996, pp. 194 and 238-242). As a result, producers of asbestos products did not face high workers' compensation insurance premiums, which would have given them an incentive to improve workplace safety. Also since workers' compensation was workers' exclusive remedy against their employers, workers could not sue their employers for damages if their workers' compensation claims were denied.

As for regulation of workplace and product safety, there were scattered federal and state programs in the 1950's and 60's, but most were voluntary and, even when rules limiting asbestos exposure were adopted, they were not enforced (Sherrill, 1972, and Brodeur, 1973). Moreover, some regulatory efforts actually increased exposure to asbestos, such as building codes that required use of asbestos insulation in the ventilation systems of commercial buildings. As the insulation aged, it deteriorated and asbestos fibers were blown throughout the buildings.

\footnotetext{
${ }^{2}$ Workers' compensation is a state-mandated insurance system that compensates workers for injuries on the job and for occupational diseases, using funds from a tax on wages. Injured workers receive partial to full replacement of wages, but no compensation for "pain and suffering."
} 
In the early 1970's, efforts to regulate workplace and consumer product safety increased with the creation of the Occupational Health and Safety Administration (OSHA) in 1970, the Environmental Protection Agency (EPA) in 1970, and the Consumer Product Safety Commission (CPSC) in 1972. OSHA quickly adopted a maximum limit of 5 asbestos fibers per cubic centimeter of air, with the standard to fall to 2 fibers in 1976. Even the 2-fiber standard was not very strict, since an exposed worker would breathe 10 million asbestos fibers in an 8-hour day. When unions and public interest groups petitioned OSHA to tighten the standard, it shortened the phase-in period for the 2-fiber standard. But a few years later when studies indicated that the 2fiber standard was not strict enough to prevent asbestosis, OSHA had become more responsive to industry concerns and it did not respond. Only in 1983 was the standard lowered again to 0.5 fibers (McCaffrey, chs. 5-6). In the late 1970s the Consumer Product Safety Commission pressured manufacturers to voluntarily remove asbestos from products such as hair dryers and children's toys. But these efforts were halted in the 1980s under the Reagan administration. In 1989, the Environmental Protection Agency proposed a ban on asbestos use. But the ban was overturned by a federal circuit court in 1991 over technical issues, and since the EPA never appealed the decision to a higher court or resubmitted the proposal, it never went into effect (Bowker, 2002). As of 2004, the U.S. has still not banned asbestos.

Thus because the large asbestos producers were able to capture the regulators, the government was very slow to limit asbestos exposure in the U.S. Since regulation largely failed, what about liability?

\section{A short history of asbestos litigation}

Workers who are harmed by asbestos products fall into two groups: those who produce the products and those who install or demolish them (such as shipyard and construction workers). While asbestos producers' liability to their own employees was limited by workers' compensation, their liability to non-employees who use their products was not. 
The liability environment became less favorable for asbestos producers in the 1960s, for several reasons. First, the number of workers' compensation claims was increasing. In 1969, Johns-Manville — the largest U.S. asbestos producer-paid nearly $\$ 1$ million in workers' compensation to 285 employees who had become disabled with asbestosis (Brodeur, 1973, p. 46). Second, a number of epidemiological studies were published in the 1960s that showed strong links between asbestos exposure and asbestosis, cancer, and mesothelioma.

Third, products liability law itself was changing. Before the 1960s, producers were liable for damage to users of their products only if producers were negligent. In practice this standard was ineffective in deterring dangerous behavior because it was difficult for plaintiffs to prove negligence, regardless of how badly producers behaved. But during the 1960s, the law of products liability moved away from the negligence standard and toward making producers "strictly liable" for damages. Under the strict liability rule, producers are liable for damage to users regardless of whether they were negligent or not, as long as their products are "unreasonably dangerous" or users were not adequately warned of the danger. This change in the law made it easier for asbestos users to win lawsuits against the asbestos manufacturers, because asbestos products were both extremely dangerous and rarely contained warnings. In response to the changed legal environment, asbestos producers began putting mild warnings on asbestos insulation starting in 1964 and on sacks of asbestos fiber in 1969 (Castleman, 1996), pp. 386-87). In theory, both the negligence and the strict liability rules give producers economically efficient incentives to increase product safety (Shavell, 1987). But in practice, the move to strict liability rule gave producers a much stronger incentive to substitute safer materials for asbestos.

The first trial in which a user of asbestos products--an insulation worker--won damages from the large asbestos manufacturers was Borel v. Fibreboard, 443 F. $2^{\text {nd }} 1076$ $\left(5^{\text {th }}\right.$ Cir. 1973), which occurred in 1973. During the following decade, 25,000 additional products liability lawsuits were filed. These lawsuits gradually became more successful as plaintiffs' lawyers obtained evidence showing that the major producers had known the dangers of asbestos exposure for decades (Brodeur, 1986). One important piece of evidence was that, during the 1930s, the major producers commissioned research that 
demonstrated the health hazards of asbestos, but kept the results secret and did not warn either their workers or product users of the danger. Evidence of a cover-up combined with defendants' failure to warn frequently led juries to award punitive as well as compensatory damages. About one-sixth of all damage awards in asbestos trials from 1987-2002 included punitive damages - a high fraction compared to other types of litigation (White, 2002a). Because punitive damages are often uninsurable, many defendants shifted from a strategy of vigorously defending against all claims to a strategy of settling. But when defendants settle claims rather than going to trial, representing claimants becomes very profitable for plaintiffs' lawyers, since most of their costs are incurred at trial. Plaintiffs' lawyers therefore began seeking out additional claimants and the volume of asbestos litigation grew. The large number of plaintiffs is one of the distinguishing features of asbestos litigation.

Plaintiffs' lawyers search for plaintiffs by screening large numbers of workers who might have been exposed to asbestos, such as textile factory workers. They file lawsuits on behalf of anyone whose X-rays show scarring or thickening of the pleural lining or the lungs. Few of these claimants have any asbestos-related impairment, but in many states they meet the legal standard for injury. Various studies have estimated that between two-thirds and nine-tenths of asbestos claimants are unimpaired and that many claims are fraudulent. But when lawsuits are settled rather than going to trial, plaintiffs' injury claims are never verified. The legal standards that allowed such a loose connection between being a plaintiff and having an actual asbestos-related disability are a second distinctive feature of asbestos litigation.

In asbestos lawsuits, plaintiffs may sue as many as 50 to 100 defendants, including all producers of products that the plaintiff might have been exposed to. Potential asbestos defendants include any firm that ever produced, installed or sold asbestos-related products, used some form of asbestos in its production process or in its products, or owned a building that contained asbestos. Defendants include Sears (sold asbestos-containing products), Gerber Baby Food (owns factories that contained asbestos), Dow Jones \& Co. (operates workplaces that contained asbestos), GM and Ford (vehicle brakes contained asbestos), and 3M (produced a respirator that did not protect users from asbestos). Plaintiffs' law firms have aggressively pursued litigation against 
insurers, too, and sometimes succeeded in collecting far more than the coverage limits of the original insurance policies. Recently, two separate insurers paid about $\$ 1$ billion each to resolve liabilities based on small insurance policies that they issued many years ago to a former distributor of asbestos insulation (Oster, 2002, and Treaster, 2003). Another insurer, MetLife, is currently being sued on the grounds that it was involved in research during the 1930's that showed the adverse health effects of asbestos, but failed to disclose the results (Oster, 2003). The extraordinarily high number of defendants is a third important factor that is distinctive about asbestos litigation.

Forum-shopping is also an important part of plaintiffs' success in asbestos litigation. During the 1980s, many asbestos claims were filed in federal courts. But federal courts rarely allow punitive damages in asbestos trials and, starting in the 1990's, they began requiring that all asbestos claims be transferred to a single federal judge in Pennsylvania for pre-trial discovery. This substantially lengthened the litigation process and, in response, most plaintiffs' lawyers shifted to filing their asbestos claims in state courts. They particularly sought out states whose laws and legal procedures favor plaintiffs and jurisdictions within those states whose judges and juries are pro-plaintiff. They also seek out individual judges who pressure defendants to settle.

Favored locations have varied over time (Carroll et al., 2002). Texas was favored in the 1990's, until it adopted legislation that limited punitive damages and restricted plaintiffs' lawyers' right to choose among jurisdictions (Glaberson, 1999). Currently favored locations include Madison County, Illinois, various counties in West Virginia, and especially Mississippi - where 20 percent of all asbestos claims are reportedly filed (Parloff, 2002). Mississippi courts favor asbestos plaintiffs in a number of ways. First, they have no limits on the size of punitive or compensatory damage awards. Second, they allow plaintiffs' lawyers to join hundreds or thousands of asbestos claims from all over the country under a single docket number (at least one plaintiff must be a Mississippi resident). Joined claims differ from class actions in that, if they go to trial, the judge or jury decides each claim separately. But they are handled as a group for pre-trial purposes and, if a trial occurs, multiple claims from the group are tried together. This increases the degree of correlation of trial outcomes, which raises the risk of trial and encourages defendants to settle (White, 2002a). For example, a recent Mississippi 
trial involved 12 asbestos plaintiffs who were selected from a group of 1,738 joined claims. The 12 plaintiffs were awarded total damages of $\$ 48$ million, with some receiving \$2 million or more despite having no detectable asbestos disease. After the trial, the judge directed the parties to settle the remaining 1,726 claims and threatened that, otherwise, he would use the same jury for the remaining claims and would direct it to consider awarding punitive damages. In response, defendants settled all claims on what were reported to be very favorable terms for plaintiffs (Parloff, 2002). Third, Mississippi courts do not require judges to approve the terms of mass settlements, which means that plaintiffs' legal fees are not subject to judicial scrutiny. As a result, although plaintiffs' lawyers gain from economies of scale in litigating large numbers of joined claims, they can still charge plaintiffs the same high legal fees-25 to $40 \%$ of settlements or damage awards--that prevail in individual litigation. Fourth, in some Mississippi counties, courts do not allow defendants to verify disease claims by conducting medical exams of plaintiffs.

White (2002a) examined the effect of forum shopping on the value of asbestos claims, using a dataset of all asbestos trials since 1987. I found that the expected value of an asbestos claim at trial in favorable jurisdictions such as Mississippi, West Virginia, and Houston, Texas, was $\$ 3$ million higher than in other jurisdictions (in 2000 dollars). When asbestos claims went to trial in groups rather than individually, plaintiffs' expected gain from trial was about $\$ 600,000$ higher. I also found that when defendants were found liable for punitive damages, their settlement costs increased sharply in later years and they attracted thousands of additional claims. Punitive damage awards signal that a defendant is a particularly vulnerable target.

One question that asbestos litigation raises is why particular states and jurisdictions are so strongly pro-plaintiff. Since state court judges are elected, one answer is that plaintiffs' lawyers contribute generously to judges' re-election campaigns in jurisdictions where they frequently file claims. Plaintiffs' lawyers have an advantage over defendants' lawyers as contributors, since they choose where to file claims and tend to file in particular jurisdictions repeatedly. If judges do not treat them favorably, they can move their claims elsewhere. Another factor is that, for a small county seat, playing host to high-stakes trials that attract many out-of-state lawyers is a form of economic 
development, supporting local hotels and restaurants and increasing the number of jobs in the county courthouse. States also gain from having pro-plaintiff laws because some plaintiffs are state residents and litigation transfers resources to them from out-of-state defendants. State court judges sometimes encourage juries to award high damages in asbestos trials on the grounds that funds for damage awards are limited and will otherwise go to residents of other states. Plaintiffs' lawyers also sometimes arrange the terms of mass asbestos settlements to reward favorable states by paying higher damages to their residents. For example, one large asbestos settlement paid damages of $\$ 263,000$ to plaintiffs who were residents of Mississippi, but only $\$ 14,000$ to plaintiffs who had the same disease but were residents of Pennsylvania or Ohio (Rothstein, 2001). But there are cost to attracting mass filings of asbestos and other tort claims--Texas changed its legal rules because of concern that excessive litigation was driving firms to leave the state (Glaberson, 1999).

Between 1982 and 2001, the total number of asbestos claimants grew from 1,000 to 600,000 , the total number of firms that have been sued grew from 300 to 6,000 , and the amount spent by defendants and insurers on asbestos litigation grew from $\$ 1$ billion to $\$ 54$ billion in nominal dollars. Because plaintiffs sue multiple defendants, the total number of asbestos claims - that is, the number of claims by individual plaintiffs against individual defendants -- is in the millions. The number of new claims filed with the Manville Trust - which pays asbestos claims for the bankrupt asbestos producer JohnsManville_-increased from about 20,000 per year in the early 1990s to 91,000 in 2001. Average damage awards in asbestos trials rose from $\$ 675,000$ in $1990-91$ to about $\$ 3$ million in 2000-03. ${ }^{3}$

\section{Lessons from Europe}

Did other countries manage the asbestos problem better than the U.S.? The answer is no. Levels of asbestos exposure were even higher in Europe than in the U.S. and consumption levels declined more slowly (see table 1). Death rates from mesothelioma

\footnotetext{
${ }^{3}$ All data are taken from Carroll et al (2002), except for the number of Manville Trust claims, which comes from www.mantrust.org, and the damage award figures, which are taken from White (2002a).
} 
as of 1998 are higher in Europe than in the U.S.: 1.85 versus 1.0 per 100,000 people, respectively. Moreover, while the death rate from mesothelioma peaked in the 1990's and is starting to decline in the U.S., it is predicted to double in Europe over the next 20 years. $^{4}$

The European countries, like Britain, mandated compensation for workers who developed asbestos disease through their workers' compensation or national insurance systems. But because of industry pressure, few workers actually received compensation so that there was little pressure on producers to reduce use of asbestos. In France, 500 new cases of mesothelioma occurred annually in the mid-1980's, but only 20-40 cases per year received compensation. Similarly in Italy, 400 new cases of mesothelioma occurred annually in the 1990's, but none received compensation between 1988 and 1995 (Castleman, p. 813). In both countries, long and complicated administrative procedures discouraged victims from filing claims. In Switzerland and the Netherlands, relatively short statutes of limitations that start from the date of exposure rather than the date of discovery of disease prevented many asbestos victims from receiving compensation. In the U.K. in 1986, there were four times the number of mesothelioma cases per capita as in the U.S., but only one-fifth the number of asbestos-related legal claims (Kazan-Allen, 2000a). Asbestos victims in the U.K. were discouraged from filing lawsuits against either the workers' compensation system or asbestos producers, because contingency fees are not allowed and the loser in a lawsuit must pay the winner's legal costs. This means that potential plaintiffs are deterred both by high initial costs and by the risk of having to pay the other side's legal costs if they lose at trial. Also, British plaintiffs cannot collect punitive damages against producers and do not have the extensive rights of discovery that enabled plaintiffs' lawyers in the U.S. to build strong cases against asbestos producers. The situation appears to have changed in the past few years, with more asbestos claims being filed and more claimants obtaining compensation, although compensation levels remain modest by U.S. standards. Ironically, one of the largest asbestos producers in the U.K., Turner and Newall Industries, went bankrupt because of the cost of paying asbestos claims by American plaintiffs who sued its U.S. subsidiary.

\footnotetext{
${ }^{4}$ European data are for the U.K., Germany, France, Switzerland, the Netherlands and Italy (Peto et al, 1999). U.S. data are from the National Cancer Institute, 2003, table I-7.
} 
Like the U.S., the European experience suggests that government regulation of asbestos was weak because of regulatory capture. But, unlike the U.S., liability did emerge as a substitute for regulation and, as a result, European asbestos producers were slower to reduce asbestos use than their counterparts in the U.S. It was only when the European countries began to adopt bans on asbestos importation and use in the 1990's that asbestos exposure fell sharply. Switzerland banned use of asbestos in 1990, and ten other European countries adopted full or partial bans during the 1990's. The European Union adopted a ban on all types of asbestos in 1999, to take effect in 2005 (KazanAllen, 2000b).

\section{The effectiveness of liability versus regulation}

Does the asbestos saga suggest any lessons concerning the effectiveness of liability versus regulation in controlling workplace and product dangers? For the U.S., neither policy was effective until the early 1970's, when OSHA imposed new limits on workplace asbestos exposure and the Borel trial occurred. The coincidence of events in that period makes it difficult to draw any conclusions. But later events suggest that liability was more effective than regulation in driving asbestos from the marketplace. In particular, the regulatory efforts of OSHA, CPSC and EPA were quite ineffective throughout the 1970's, while the Borel trial was followed by a litigation explosion. By the late 1970's, producers had eliminated asbestos from many products and overall U.S. consumption had declined sharply. However for Europe, neither liability nor regulation was effective until later.

The asbestos saga also suggests that, the worse the failure of regulation, the more likely that the courts will respond with high liability. This is because the callous behavior of producers in consciously exposing workers and product users to danger tends to make judges and juries very sympathetic to plaintiffs. In the asbestos context, this caused judges to change the law in asbestos victims' favor and juries to award high compensatory and punitive damages.

\section{Is Asbestos Different from Other Mass Torts?}


Several mass torts involving personal injury have been largely or fully resolved in recent years: for example, the Fen-Phen diet supplement litigation was resolved in 2000; a settlement of the tobacco claims involving the 50 states was reached in 1998; claims for harm due to breast implants were resolved in 1994; the Dalkon Shield (intrauterine contraceptive device) litigation was settled in 1988, and the Agent Orange litigation was settled in 1984. Along with asbestos, a number of other mass torts are still in litigation, including claims of harm due to lead exposure, firearms, and fast food, and individual claims involving harm from tobacco. Table 2 gives some characteristics of asbestos and other mass torts involving personal injury. In this section I consider how asbestos differs from other mass torts and how asbestos litigation might be resolved.

\section{Number of Defendants and Plaintiffs}

While 600,000 people have filed asbestos claims so far, other mass torts also have hundreds of thousands of claimants. The Agent Orange litigation eventually involved about 250,000 claimants and the breast implant litigation involved 440,000. Tobacco and fast food litigation potentially involve many more plaintiffs than asbestos, since huge numbers of Americans smoked or are obese. But while many plaintiffs are necessary for a mass tort, they are not sufficient. There must also be funds to pay high damages.

Where asbestos differs strongly from other mass torts is in the number of defendants involved. About 6,000 defendants have been sued for asbestos damage, while no previous mass tort has had more than about a dozen. Because so many firms were involved with asbestos production, plaintiffs' lawyers have been able to substitute new defendants as old ones go bankrupt. Also the large number of defendants means that there are many insurers with obligations to pay. As a result, even with hundreds of thousands of asbestos claims, there are enough deep pockets to keep the litigation going.

\section{The Law is Different for Asbestos}

Asbestos developed its own legal doctrines that differ from those applied in other areas of tort litigation. One difference is that the burden on asbestos claimants of 
proving causation is lower. Normally, plaintiffs must show that a particular defendant's product caused their harm. Providing this kind of evidence would be difficult for most asbestos plaintiffs, since they often were exposed to many different asbestos products and cannot establish that any particular product caused their harm. In response, courts loosened the rules of causation, so that asbestos plaintiffs were only required to present evidence that particular defendants' products were used at their workplaces. Coworkers' recollections of seeing a particular product in the workplace are usually allowed, even though this type of evidence would not normally be admitted in court (Brickman, 1992). Asbestos is not the first mass tort in which relaxed standards of causation have been used-an earlier example is litigation over the drug DES, which harmed the daughters of women who took it during pregnancy. Because multiple manufacturers produced DES and victims did not know which manufacturer's DES harmed them, all were found liable for damages based on their market shares. But many mass torts remain small because plaintiffs cannot meet the burden of demonstrating causation. For example in the lead paint litigation, plaintiffs generally lose lawsuits against paint manufacturers, because the ir homes have many layers of lead paint and they cannot show that any particular manufacturer's paint caused their harm (Dean, 2001, and Cupp, 2000).

Another way that asbestos claims differ from other tort claims is in how claimants with no asbestos-related impairment are treated. Under normal tort law, the ir claims would not be allowed to proceed in the legal system, because they have not suffered any harm. Some state courts follow this general approach by putting these claims on an "inactive docket," which preserves plaintiffs' right to sue in the future if they develop a serious asbestos disease, but otherwise prevents their claims from proceeding. Other states allow these claimants to collect for "asbestos exposure" or for "fear of cancer." Still others allow them to collect twice, once for asbestos exposure and again for a disabling asbestos disease if one develops in the future. At trial, asbestos plaintiffs who have exposure only (for example, they have pleural plaque but are not disabled or injured) have been awarded damages as high as $\$ 5$ million and they have also received high settlements. 
Other legal developments have expanded insurers' liability for asbestos claims. Suppose a plaintiff was exposed to asbestos in 1955 and diagnosed with asbestosis in 1985. Under the "triple trigger" doctrine that many states have adopted, inhaled asbestos fibers are treated as continuously injuring plaintiffs' lungs, so that a plaintiff can collect from the insurers that covered the firm in 1955, in 1985, and any date in-between. By allowing a single plaintiff to claim under many insurance policies, the doctrine increases the amount of compensation that victims can collect. In addition, courts have reinterpreted many products liability insurance policies as "premises liability" policies. Products liability policies have an aggregate limit on coverage, but premises policies which were intended for perils such as fire and hurricanes -- have only a coverage limit for each occurrence. If each asbestos claim is treated as a separate occurrence, then insurers effectively have unlimited liability (Rheingold, 1996). The result of these changes in insurance law is to greatly expand insurers' liability for asbestos claims.

Why did tort law as applied to asbestos claims change so dramatically and in so many ways? Concerning insurers' liability, one answer is that the policies were vague and judges applied a principle of insurance law that requires construing ambiguous insurance contracts against the interest of the insurer. Another answer is that judges' indignation at asbestos defendants' callous behavior sometimes led them to give juries instructions that favored plaintiffs. And once plaintiffs win a case and the decision survives on appeal, the case becomes a precedent that increases plaintiffs' probably of winning later cases.

\section{The search for the "next asbestos"}

Plaintiffs' lawyers have long been searching for the next big mass tort, but with the exception of tobacco, no other mass tort has achieved the same scale. Some mass torts, including the lead paint litigation, have remained small because plaintiffs have not been able to establish causation and the courts have not loosened the requirements, as they did for asbestos claimants. In other mass torts, causation can be established, but defendants have been found not liable because they provided adequate warnings of the dangers of using their products or because the design of the product was not defective. Thus in the 
firearms litigation, most lawsuits brought by gun victims have been dismissed on the grounds that guns cause injury because they are not defective, while manufacturers are only liable for harm when their products are defective (Kimball and Olson, 2000). In any case, firearms litigation will probably remain small, both because there are only a few gun manufacturers and because Congress may end the litigation by passing legislation to protect gun manufacturers from liability.

In the tobacco litigation, there is a long history of individual smokers losing lawsuits against cigarette manufacturers, because juries considered the Congressionallymandated warnings on cigarette packages to be sufficient and therefore smokers were held to have assumed the risks of smoking. Because individual plaintiffs were unsuccessful, several state attorneys-general decided in 1994 to bring suit against the tobacco companies. To keep the states' initial costs down, private law firms were hired to represent the states on a contingency fee basis, i.e., the law firms would be paid a share of whatever damages the states received. After several false starts, the tobacco companies and all 50 states concluded settlements in 1997-98 which required the tobacco industry to pay the states $\$ 246$ billion (undiscounted) over 25 years (Derthick, 2002). The tobacco settlement did not bar individual plaintiffs from suing the tobacco companies, however, and in 2000 a jury in Florida awarded punitive dama ges of $\$ 145$ billion to a class of 500,000 Florida smokers (Bragg, 2000). Thus despite the settlement with the states, tobacco litigation still has the potential to grow.

Finally, fast food litigation is at an early stage, but will probably never be as large as asbestos (Ives, 2002). Plaintiffs seem unlikely to succeed in their lawsuits, simply because there are so many different ways of over-eating. Also, while punitive damages were an important element in the growth of asbestos litigation, juries seem unlikely to develop a similar level of outrage over McDonald's promotion of hamburgers as they did over asbestos producers' extreme disregard of workers' and users' safety.

\section{High legal fees and future mass torts}

Asbestos litigation has gene rated a massive transfer to lawyers, far greater than any other mass tort. The combination of plaintiffs' and defendants' legal expenses consumed 
about 66 percent of asbestos compensation paid during the 1980s and about 60 percent of compensation paid during the 1990s (Carroll et al, 2002). Based on these figures, of the $\$ 54$ billion already spent on asbestos litigation, about $\$ 34$ billion went to lawyers. If total asbestos litigation costs eventually reach $\$ 200$ billion, then legal fees could consume an additional $\$ 88$ billion.

These legal fees far exceed even the enormous amounts paid to lawyers in the tobacco settlement. Suppose we assume that plaintiffs' lawyers received half of the $\$ 34$ billion already paid to lawyers in asbestos litigation, or $\$ 17$ billion as of 2000 . In contrast, plaintiffs' lawyers earned a total of \$13 billion (undiscounted) from the 50 states in the tobacco settlement, but the money is to be paid out over 25 years (Derthick, 2002).

High profits from asbestos litigation have changed the legal industry by encouraging more lawyers to enter the business of representing mass tort plaintiffs and providing start-up funds and expertise for new mass torts. The same plaintiffs' law firms that got their start representing asbestos claimants later represented the states in the tobacco litigation. They also initiated other mass torts including lead paint, firearms, Fen-phen, health care fraud, and fast food, as well as representing victims in the Ford/Firestone defective tire litigation and the World Trade Center attacks. Many of the innovations that plaintiffs' lawyers developed in representing asbestos claimants_including concentrating claims in favorable state courts, joining large numbers of claims together, and suing insurers for funds well beyond the limits of their insurance policies - are likely to used in future mass torts. Plaintiffs' lawyers have also become large contributors to political campaigns of favorable candidates, including candidates for state judgeships, state attorneys-general, and Congress. Several have run for Congress themselves (Derthick, 2002, p. 187). As a result of the growth of asbestos litigation, future mass torts are likely to be more numerous and more expensive and future legislation that plaintiffs' lawyers oppose is less likely to be passed.

\section{Bankruptcies Resolve Other Mass Torts, But Not Asbestos}

Bankruptcy proceedings are designed to resolve all claims against a bankrupt firm, including both current claims and claims that will come due in the future. As a 
result, they are one method of resolving mass torts. This is clearest in a Chapter 7 bankruptcy liquidation. Here the bankrupt company's assets are sold, either as a going concern or piecemeal, and it ceases to exist. The sale proceeds are used to pay all claims, including tort claims, according to a predetermined priority ordering. If the bankrupt company instead reorganizes under Chapter 11, it continues to operate rather than shutting down. Creditors then must approve a reorganization plan that provides for partial payment of all claims, with the funds coming mainly from the reorganized firm's future profits. This procedure preserves the company's going concern value by allowing it to emerge from Chapter 11 free of its tort and other pre-bankruptcy claims (White, 1989).

Most mass tort defendants that file for bankruptcy reorganize under Chapter 11. For bankrupt asbestos defendants, this makes sense economically because most of them no longer produce asbestos-containing products and would be profitable if not for their asbestos liabilities. The reorganization plan always involves setting up a compensation trust that takes over responsibility for paying present and future asbestos claims. The funding for the trust comes from the reorganized firm's future profits and from its insurers, who contribute money to the trust in return for a discharge from liability to the firm's tort claimants. ${ }^{5}$

Bankruptcy filings were used successfully to resolve the Dalkon Shield and breast implant mass torts. But while many asbestos producers have filed for bankruptcy, these bankruptcies have worsened the asbestos crisis rather than resolving it, by spreading the litigation to new defendants. The problem is that, when an asbestos defendant goes bankrupt, it stops paying claimants until its compensation trust begins to operate and even then, the value of payments will be low. As a result, plaintiffs' lawyers shift their litigation focus to non-bankrupt defendants, since the latter are more lucrative. In addition, many states have "joint and several liability," which means that each defendant found liable for a damage award is responsible for paying up to the entire amount if other defendants don't pay their shares. Therefore, when one defendant goes bankrupt,

\footnotetext{
5 In 1994, Congress adopted a set of amendments to the Bankruptcy Code that apply only to bankruptcies of firms with asbestos claims. The amendments require that a compensation trust be set up. They also specify special voting rules for adoption of reorganization plans-see below. White (2002b) discusses recent asbestos bankruptcies and reorganization plans.
} 
the remaining defendants' liability increases. Similarly, if an insurer fails, some of its asbestos liabilities are transferred to other insurance companies, because multiple insurers are liable for the same claims under the triple trigger doctrine.

Thus an important problem with bankruptcy is that it contains no mechanism for coordinating among multiple defendants that share liability for tort claims. As a result, bankruptcies by individual asbestos defendants shift liability to non-bankrupt defendants and therefore spread the asbestos crisis rather than resolving it.

Bankruptcy filings by asbestos defendants also create additional distortions. One is that in order for a bankrupt asbestos firm's reorganization plan to be adopted, 75 percent of current tort claimants must vote in favor of the plan, but future tort claimants do not have the right to vote at all. (The 75 percent approval requirement is higher than the normal standard for adopting reorganization plans.) As a result, asbestos reorganization plans over-compensate present claimants relative to future claimants. Another problem is that if asbestos producers expect to file for bankruptcy, their managers have an incentive to encourage the filing of claims by the unimpaired. After all, these claimants have an incentive to vote in favor of a reorganization plan even if it provides only low compensation, and because there are too few claimants with serious asbestos diseases to block adoption of the plan, those with serious diseases tend to be under-compensated (White, 2002b). Thus the voting rules for adoption of asbestos firms' reorganization plans lead to over-compensation of unimpaired claimants and under-compensation of future claimants and those with serious asbestos diseases. This pattern of compensation further increases the cost of asbestos litigation by encouraging plaintiffs' lawyers to continue filing additional claims by the unimpaired.

\section{No Class Action Settlement of Asbestos Claims}

Another method that the legal system has developed for resolving mass torts is the class action settlement, which was successfully used to resolve both the Agent Orange and Fen-Phen litigation. In a class action, a judge certifies a class consisting of all plaintiffs having a particular type of claim against one or more defendants that produced a harmful product. If the class action goes to trial, the judge or jury makes a single 
decision for each defendant — that is, all plaintiffs either win or lose against each defendant. But most class actions are resolved by settlements rather than trials and class actions frequently are certified only after a settlement is reached. As in a bankruptcy, class action settlements often involve setting up a compensation trust to pay all present and future tort claims, using assets provided by the defendant and its insurers.

An important advantage of class action settlements is that they can be used to collectively resolve mass torts that involve multiple defendants. If multiple defendants produced a single dangerous product and individual plaintiffs cannot identify which defendant's product harmed them, a class action settlement can set up a single compensation trust to pay all plaintiffs' claims, with defendants and insurers agreeing on a formula for dividing the cost. Unlike bankruptcy filings by individual defendants, a class action settlement of this type prevents the mass tort from spreading. The settlement of the Agent Orange litigation followed this pattern-claims against all twelve producers of Agent Orange were resolved collectively by creating a single compensation trust.

During the mid-1990's, the asbestos mass tort seemed to be headed for resolution using this route. A large class action settlement was agreed on and certified that involved all of the tort claims against the Center for Claims Resolution, a consortium of twenty asbestos producers that were conducting their legal defenses jointly. But in Amchem Products v. Windsor, 521 U.S. 591 (1997), the Supreme Court overturned the class certification. Two years later in Ortiz v. Fibreboard Corp., 527 U.S. 815 (1999), the Supreme Court overturned the certification of another asbestos class action settlement that involved only a single large defendant. After the two decisions, defendants concluded that no class action settlement of asbestos claims would succeed and 22 of them quickly filed for bankruptcy (Hensler, 2002).

Economists have strongly criticized the federal rules that determine when a class action can be certified, arguing that judges certify class actions too frequently. Their concern is that class actions are often certified even when plaintiffs' claims are very weak and they would lose in a trial. The problem is that, once a class is certified, defendants nearly always settle since going to trial is too risky when losing could force the firm into bankruptcy (Priest, 1997). But economists have overlooked a benefit of certifying class actions in the mass tort context, which is that they can be used to resolve 
multi-defendant mass torts collectively and can therefore stop the spread of mass torts to new defendants.

But in the asbestos context, even if the Supreme Court justices changed their minds and allowed a large class action of all asbestos claimants to be certified, it would probably be impossible for the parties to agree on a settlement. Plaintiffs and defendants would have to agree on how much is needed to compensate all present and future claimants and defendants and insurers would have to agree on a formula for dividing the cost. The agreement concerning the cost allocation would have to be voluntary, since class action settlements have no mechanism for forcing dissenting defendants to agree (in contrast, dissenting plaintiffs can be forced to agree since only the judge must approve the settlement). And while asbestos has 6,000 defendants, the largest number of defendants in a single mass tort class action settlement so far has only been a dozen -- in the Agent Orange litigation. Schuck (1986) discusses how difficult it was for the twelve Agent Orange defendants to reach a settlement, even with an activist judge who forced them to bargain around the clock and refused to let them out until they reached an agreement.

The arguments of this section suggest that, while asbestos litigation shares many characteristics with other mass torts, it is the only one that defies resolution within the court system. Given the large number of asbestos defendants, collective solution mechanisms such as class action settlements and bankruptcy that worked for other mass torts do not work for asbestos. In addition, since most asbestos litigation occurs in state courts, tort reforms at the state level would be ineffective unless they were adopted simultaneously by a number of states. This is because reforms adopted by a particular state would either have no effect, if the state has few asbestos claims, or would merely shift the focus of litigation to the next-most-favorable state, if the state has many asbestos claims. In the next section, I discuss how Congress proposes to solve the asbestos crisis.

\section{Legislative Solutions to the Asbestos Crisis}


In Ortiz v. Fibreboard, 527 U.S.815 (1999), Supreme Court Justice David Souter wrote that "the elephantine mass of asbestos cases ... defies customary judicial administration and calls for national legislation." An ideal solution to the asbestos litigation mess would accomplish several goals: 1) compensate present and future claimants equitably based on their harm, but do not compensate those who are unimpaired; 2) reduce litigation costs; 3) resolve uncertainty for claimants, defendants and insurers; and 4) stop the spread of claims to new defendants that had little or no involvement in asbestos production.

Congress is now considering the "Fairness in Asbestos Injury Resolution Act of 2003," S. 1125, which would resolve the asbestos crisis by establishing a privatelyfunded, publicly-run administrative procedure for compensating asbestos victims. Asbestos defendants and insurance companies would each pay a total of $\$ 52$ billion to the fund over 27 years. An additional $\$ 10$ billion in assets would be transferred to the fund from existing asbestos compensation trusts that were set up as part of asbestos bankruptcies, for a total of $\$ 114$ billion. Defendants would be required to pay either a proportion of their revenues or a flat dollar amount to the fund each year, with the obligation depending on individual defendants' size and past asbestos liabilities. Small businesses and firms with no previous asbestos liabilities would be exempt. For insurers, a commission would be established to determine individual companies' assessments, which are to depend on past exposure to asbestos liabilities.

To receive compensation, claimants must provide evidence showing that they had particular levels of exposure to asbestos for at least a minimum number of years and must submit medical evidence to prove that they have a qualifying asbestos disease. (Specific requirements vary by disease.) Claimants are not required to show that they were harmed by particular asbestos products. The act specifies that independent medical experts will review all applications for compensation and it also gives the fund authority to require that claimants submit to medical examinations and provide tissue biopsies.

Proposed compensation levels are shown in Table 3. Claimants with mesothelioma would receive \$1 million, those with asbestos-related cancers would receive between $\$ 25,000$ and $\$ 1$ million (depending on disease and smoking behavior), and those with severe or disabling asbestosis would receive between $\$ 300,000$ and 
$\$ 750,000$ (depending on severity). Claimants with no impairment would receive free medical monitoring, but no cash. Compensation would be paid over three to four years and future payments would be inflation-adjusted. Table 3 also shows expected asbestos compensatory damage awards at trial since 1987 (punitive damage awards are excluded since payments by the fund are intended to be compensatory only). The comparison suggests that the act's proposed compensation levels for severe asbestos diseases are in the same range as compensatory damage awards at trial. But most tort claimants receive much less, since claims are generally settled out of court and settlement levels are much lower than damage awards. ${ }^{6}$ The act also includes a long-overdue ban on asbestos use.

Another way to estimate the adequacy of the proposed fund is to use figures on the annual number of new lawsuits filed by plaintiffs with serious asbestos disease. Currently, about 2,000 new lawsuits are filed each year filed by plaintiffs with mesothelioma, 2,000 to 3,000 are filed by plaintiffs with other asbestos-related cancers, and a "smaller number" are filed by plaintiffs with serious asbestosis (Biggs et al., 2001). To err on the high side, suppose both of the latter figures are 3,000 per year. Also suppose that the fund pays mesothelioma victims $\$ 1$ million each, other cancer victim $\$ 512,500$ each, and asbestosis victims $\$ 385,000$ each (the latter two figures are the midpoints of the act's proposed ranges). Then compensating all claimants wo uld cost $\$ 4.7$ billion per year, so that the $\$ 114$ billion dollar fund would be adequate to pay all claims for the next 24 years. Since the number of new cases of serious asbestos disease is likely to decline over time, this approach also suggests that the proposed fund would be adequate.

Another way to estimate the adequacy of the proposed fund is to use figures on the annual number of new lawsuits filed by plaintiffs with serious asbestos disease. Currently, about 2,000 new lawsuits are filed each year filed by plaintiffs with mesothelioma, 2,000 to 3,000 are filed by plaintiffs with other asbestos-related cancers, and a "smaller number" are filed by plaintiffs with serious asbestosis (Biggs et al., 2001). To err on the high side, suppose both of the latter figures are 3,000 per year. Also suppose that the fund pays mesothelioma victims $\$ 1$ million each, other cancer victims

\footnotetext{
${ }^{6}$ Data on settlement levels broken down by disease are not available. The average asbestos settlement level for all diseases is about $\$ 5,000$ (in 2000 dollars), but claimants usually receive separate settlements from multiple defendants. Damage and settlement figures are calculated from data described in White (2002a).
} 
$\$ 512,500$ each, and asbestosis victims $\$ 525,000$ each (the latter two figures are the midpoints of the act's proposed ranges). Then compensating all claimants would cost $\$ 5.1$ billion per year, so that the $\$ 114$ billion dollar fund would be adequate to pay all claims for the next 22.3 years. Since the number of new cases of serious asbestos disease is likely to decline over time, this approach also suggests that the proposed fund would be adequate.

How well might a fund of this sort accomplish the four goals named at the beginning of this section? $\$ 114$ billion appears to be enough to compensate present and future claimants, but only if the fund is aggressive in weeding out claims by the unimpaired. In order to do so, it will have to spend substantial resources on auditing claims, conducting medical examinations and examining biopsies, even though these activities are expensive. Past experience by the Manville Trust suggests that, without careful auditing, claimants with pleural plaque will claim to have asbestosis, claimants with asbestosis who are unimpaired will claim to be disabled, and the number of claims will increase rapidly. These factors will quickly cause the fund to overrun its budget.

Will adoption of the fund reduce litigation costs relative to the current system? The answer is unclear, since the fund's own cost of auditing claims will be high and, on the other side, the act does not specify limits on plaintiffs' attorneys' fees. Other asbestos compensation trusts, including the Manville Trust, often limit plaintiffs' attorneys' fees to $25 \%$ of compensation. But, perhaps to reduce opposition by plaintiffs' lawyers, the act's drafters did not set any limits (although they specified that a legal assistance program for claimants be set up).

The fund would certainly give greater certainty to all parties. Claimants would receive a uniform level of compensation by disease, in comparison to the tort system where they individually bear the risk of winning a multi-million dollar damage award at trial, losing at trial and receiving nothing, or receiving much smaller settlements. Adoption of the fund also increases the probability that money will be available to compensate individuals who develop serious asbestos diseases in the future. Claimants would also receive their compensation more quickly than in the tort system, where lawsuits often take many years. The fund also eliminates defendants' uncertainty 
concerning their future asbestos liabilities and stops the spread of asbestos litigation to new defendants.

Whether the act will be adopted is unclear. While defendants and insurers have agreed to the $\$ 114$ billion figure, the AFL-CIO announced in the fall of 2003 that at least $\$ 153$ billion is needed and Democrats in the Senate have backed the AFL-CIO's demand.

An alternative approach for resolving the asbestos crisis would also new legislation, but would be less complicated than the fund-based approach It would require, first, that all asbestos claims be filed in federal court and, second, that all asbestos claims be transferred to a single federal judge for pre-trial discovery and trial. (Currently, many asbestos lawsuits are transferred to a particular federal judge for pretrial discovery, but they are returned to the jurisdiction where they were filed for trial.) Third, claims involving mesothelioma, asbestos-related cancers, and severe asbestosis would be placed on an "active docket," while all other asbestos claims would be placed on an inactive docket. Only claims on the active docket would proceed. Congress would need to provide sufficient resources for the court to audit all claims for disease type and to process all claims on the active docket. At current rates, there would be about 8,000 new active docket claims each year, which—given settlements—would require that several hundred trials be conducted each year. (These figures would be expected to decline over time.) By reducing the amount spent on compensating claimants with no asbestos-related disability, this approach would at least partially achieve the four goals specified above. It would also eliminate the need for agreement on how to pay for a compensation fund.

\section{Conclusion}

The asbestos litigation mess is a combination of a difficult situation and a series of unwise decisions. The difficult situation was that asbestos was so widely used, so demonstrably harmful to health, and a number of firms engaged in cover-ups and political pressure to hide their behavior. The bad decisions include preventing workers with asbestos-related diseases from collecting workers' compensation; not regulating asbestos 
until the 1970s; not banning asbestos in the early 1990's; allowing uninjured claimants to collect damages; allowing asbestos liability to spread to defendants with little asbestos involvement; and rewriting the meaning of past insurance policies to increase insurers' liability.

The asbestos situation suggests several lessons that may be applicable to other mass torts. First, because of capture by the large asbestos producers, regulation was ineffective in preventing large-scale asbestos exposure. However the large producers were unable to capture the courts and liability was eventually effective in driving asbestos from the U.S. marketplace. Second, regulation and liability are related in the sense that, the worse is the regulators' failure, the stronger the courts' reaction is likely to be. Thus when producers knowingly expose large numbers of workers and consumers to highly dangerous products and attempt to cover up their behavior, judges and juries are likely to respond by punishing them with massive compensatory and punitive damages. Third, asbestos is fairly unique as a mass tort because it was used in thousands of products, millions of plaintiffs were exposed, and thousands of defendants with deep pockets were potentially liable. This made it more likely that once the litigation got started, it would spiral out of control. But it also means that the same scenario is unlikely to happen for other mass torts. After all, plaintiffs' lawyers have been searching for the next asbestos for years now, and, so far, they don't seem to have found it.

Fourth, the legal system has two methods to collectively resolve mass torts-bankruptcy and class action settlements--but neither of them worked for asbestos. Bankruptcy is effective in resolving mass torts that involve only a single defendant, but not in resolving those with many defendants, because it has no mechanism for preventing the spread of liability from bankrupt to non-bankrupt defendants. A large class action settlement could potentially resolve mass torts involving multiple defendants, but the Supreme Court blocked this route for asbestos and, in any case, it would be near impossible to get 6,000 defendants and hundreds of insurers to voluntarily agree on a settlement. By a simple process of elimination, this suggests that Congress will eventually have to pass legislation to resolve the asbestos crisis. But, not surprisingly, the current bill in Congress is stalled over the same issue-how to decide on individual defendant's and insurer's contribution to the compensation fund. 
Finally, while other mass torts are unlikely to replicate the size and scope of asbestos litigation, the legal techniques and precedents that lawyers developed for asbestos litigation are likely to be applied to other mass torts in the future. As a result, mass torts in the future will be more common and more expensive.

Will the asbestos mess at least have the beneficial effect of changing firms' attitudes toward the risks of using asbestos-like products in the future? Unfortunately, neither liability nor regulation works very well when the harm that results from exposure has a long latency period like that of asbestos. Because managers tend to heavily discount the future, if they can increase profits for 20 or more years by using dangerous substances, they are likely to ignore the high price that their firms and society will eventually pay. 


\title{
Table 1:
}

\section{Consumption of Asbestos in the U.S. versus Europe}

\author{
(metric tons per million population)
}

$\begin{array}{llrrlr} & \text { UK } & \text { Germany } & \text { France } & \text { US } & \text { World } \\ 1970 & 6.69 & 3.91 & 5.32 & 3.46 & 0.92 \\ 1975 & 5.46 & 5.57 & 5.24 & 3.01 & 1.05 \\ 1980 & 3.07 & 4.07 & 3.42 & 1.53 & 1.05 \\ 1985 & 1.04 & 1.08 & 1.13 & 0.63 & 0.91 \\ 1990 & 0.92 & 0.58 & 3.40 & 0.20 & 0.80\end{array}$

Notes: Figures for the UK, France and Germany are calculated from the value of asbestos imports per million population, taken from the NBER Trade Database, Disk 2, World Trade Flows, 1970-1992. Import figures are converted to tons consumed using price data from the Statistical Abstract of the U.S., various editions. (None of the three European countries produces asbestos.) Figures for the U.S. and the world are based on consumption of asbestos, taken from Castleman (1996, pp. 788 and 838). Population figures are from U.S. Census Bureau, International Data Base, www.census.gov/ipc/www/idbnew.html. 
Table 2:

Characteristics of Personal Injury Mass Torts

\begin{tabular}{|c|c|c|c|c|c|c|}
\hline & $\begin{array}{l}\text { type of } \\
\text { product }\end{array}$ & $\begin{array}{l}\text { number of } \\
\text { defendants }\end{array}$ & $\begin{array}{l}\text { numberl } \\
\text { type of } \\
\text { plaintiffs }\end{array}$ & $\begin{array}{l}\text { amount } \\
\text { of } \\
\text { compen- } \\
\text { sation } \\
\text { fund } \\
\end{array}$ & $\begin{array}{l}\text { year } \\
\text { resolved }\end{array}$ & type of resolution \\
\hline Asbestos & $\begin{array}{l}\text { insula- } \\
\text { tion and } \\
\text { other } \\
\text { products }\end{array}$ & $\begin{array}{l}6,000 \text { as } \\
\text { of } 2000\end{array}$ & $\begin{array}{c}600,000 \text { as } \\
\text { of } 2000\end{array}$ & & & $\begin{array}{c}\text { individual } \\
\text { defendant } \\
\text { bankruptcies } \\
\text { only }\end{array}$ \\
\hline $\begin{array}{l}\text { Agent } \\
\text { Orange }\end{array}$ & $\begin{array}{l}\text { defoliant } \\
\text { used in } \\
\text { the } \\
\text { Vietnam } \\
\text { War }\end{array}$ & 12 & 250,000 & $\begin{array}{c}\$ 180 \\
\text { million }\end{array}$ & 1984 & $\begin{array}{c}\text { class action } \\
\text { settlement }\end{array}$ \\
\hline $\begin{array}{l}\text { Dalkon } \\
\text { Shield }\end{array}$ & $\begin{array}{l}\text { defective } \\
\text { I.U.D. }\end{array}$ & 1 & 140,000 & $\begin{array}{l}\$ 2.3 \\
\text { billion }\end{array}$ & 1988 & bankruptcy \\
\hline $\begin{array}{l}\text { Breast } \\
\text { implants }\end{array}$ & $\begin{array}{l}\text { silicon } \\
\text { gel } \\
\text { breast } \\
\text { implants }\end{array}$ & 3 & 440,000 & $\begin{array}{c}\$ 4.2 \\
\text { billion }\end{array}$ & 1994 & $\begin{array}{c}\text { class action } \\
\text { settlement (later } \\
\text { the main } \\
\text { defendant filed } \\
\text { for bankruptcy) }\end{array}$ \\
\hline $\begin{array}{l}\text { Fen- } \\
\text { Phen }\end{array}$ & $\begin{array}{c}\text { diet } \\
\text { drugs }\end{array}$ & 1 & $\begin{array}{c}\text { filing } \\
\text { period still } \\
\text { open }\end{array}$ & $\begin{array}{l}\$ 3.76 \\
\text { billion }\end{array}$ & 2000 & $\begin{array}{c}\text { class action } \\
\text { settlement (non- } \\
\text { mandatory) }\end{array}$ \\
\hline Tobacco & $\begin{array}{l}\text { cigar- } \\
\text { ettes }\end{array}$ & 4 & $\begin{array}{c}0 \text { U.S. } \\
\text { states }\end{array}$ & $\begin{array}{c}\$ 246 \\
\text { billion }\end{array}$ & 1998 & $\begin{array}{c}\text { settlement } \\
\text { between } 50 \\
\text { states and the } \\
\text { tobacco } \\
\text { companies } \\
\text { (private lawsuits } \\
\text { still pending) }\end{array}$ \\
\hline Lead & $\begin{array}{c}\text { leaded } \\
\text { paint }\end{array}$ & & $\begin{array}{c}\text { state and } \\
\text { local govts }\end{array}$ & & & none \\
\hline Firearms & guns & & $\begin{array}{c}\text { cities, } \\
\text { counties, } \\
\text { U.S. govt } \\
\text { and private } \\
\text { plaintiffs } \\
\end{array}$ & & & none \\
\hline Fast food & $\begin{array}{l}\text { ham- } \\
\text { burgers, } \\
\text { etc. }\end{array}$ & & $\begin{array}{l}\text { private } \\
\text { plaintiffs }\end{array}$ & & & none \\
\hline
\end{tabular}


Sources: Mintz (1985) for Dalkon Shield; Schuck (1986) for Agent Orange; Tidmarsh (1998) and Rheingold (1996, p. 3.31) for breast implants; Dean (2001) and Butterfield (2003) for lead paint and firearms; Derthick (2002) for tobacco; Ives (2002) for fast food. 


\section{Table 3: \\ Proposed Compensation Levels under S. 1125 and Expected Compensatory Damage Awards in Asbestos Trials}

\begin{tabular}{|l|c|c|}
\hline & $\begin{array}{c}\text { Proposed } \\
\text { compensation } \\
\text { under S. 1125 }\end{array}$ & $\begin{array}{c}\text { Expected } \\
\text { compensatory } \\
\text { damage awards, } \\
1987-2002\end{array}$ \\
\hline Mesothelioma & $\$ 1,000,000$ & $\$ 2,340,000$ \\
\hline $\begin{array}{l}\text { Lung and other } \\
\text { cancers }\end{array}$ & $\$ 25,000-\$ 1,000,000$ & $\$ 760,000$ \\
\hline Asbestosis & $\$ 300,000-\$ 750,000$ & $\$ 460,000$ \\
\hline
\end{tabular}

Note: Compensatory damage awards are in 2000 dollars and are calculated from data described in White (2002a). Punitive damage awards are excluded from the calculations. Damage awards take into account plaintiffs' probability of losing at trial, which is approximately one-third. 


\section{References}

Biggs, Jennifer L., et al. 2001. Overview of Asbestos: Issues and Trends. Report prepared by the American Academy of Actuaries Mass Torts Work Group. www.actuary.org/pdf/casualty/mono_dec01asbestos.pdf

Bragg, Rick. 2000. “Juror Says a 'Sense of Mission' Led to Huge Tobacco Damages.” New York Times, July 16, 2000.

Bowker, Michael. 2003. Fatal Deception: The Untold Story of Asbestos. Rodale.

Brickman, Lester. 1992. "The Asbestos Litigation Crisis: Is There A Need For An Administrative Alternative?" Cardozo L. Rev., vol. 13, p. 1819.

Brodeur, Paul. 1985. Outrageous Misconduct: The Asbestos Industry on Trial. New York: Pantheon Books.

Brodeur, Paul, 1973. Expendable Americans. New York: Viking Press.

Carroll, S.J., D. Hensler, A. Abrahamse, J. Gross, M.White, S. Ashwood, and E. Sloss. 2002. Asbestos Litigation Costs and Compensation: An Interim Report. Santa Monica: RAND Corporation, DB-397-ICJ.

Castleman, Barry I. 1996. Asbestos: Medical and Legal Aspects, $4^{\text {th }}$ edition. Englewood Cliffs, NJ: Aspen Law \& Business.

Cupp, Richard L., Jr. 2000. "Beyond Tobacco Symposium: Tort Issues in Light of the Cigarette Litigation: State Medical Reimbursement Lawsuits after Tobacco: Is the Domino Effect for Lead Paint Manufacturers and Others Fair Game?" Pepperdine Law Review, vol. 27, p. 685.

Dean, Amber E. 2001. "Lead Paint Public Entity Lawsuits: Has the Broad Stroke of Tobacco and Firearms Litigation Painted a Troubling Picture for Lead Paint Manufacturers?" Pepperdine Law Review, vol. 28, p. 915.

Derthick, Martha A. 2002. Up in Smoke: From Legislation to Litigation in Tobacco Politics. Washington, D.C.: CQ Press.

Gibson, S. Elizabeth. 2000. Case Studies of Mass Tort Limited Fund Class Action Settlements and Bankrutpcy Reorganizations. Wash., D.C.: Federal Judicial Center.

Glaberson, William. 1999. "Some Plaintiffs Losing Out In Texas' War on Lawsuits," New York Times, June 7, 1999. 
Hensler, Deborah R. 2002. "As Time Goes By: Asbestos Litigation After Amchem and Ortiz," Texas Law Review, vol. 80, pp. 1899-1924.

Ives, Nat. 2002. "Food companies are urged to act to deflect blame for the nation's increase in obesity," New York Times. Dec 4, 2002, pg. C4.

Kazan-Allen, Laurie. 2000. “Asbestos Compensation in Europe," Newsletter, International Ban Asbestos Secretariat, www.btinternet.com/ ibas/f_lka_eu_comp.htm.

Kazan-Allen, Laurie. 2000. "Europe Bans Asbestos," Newsletter, International Ban Asbestos Secretariat, www.btinternet.com/ ibas/f_lka_eu_comp.htm.

Kimball, Anne G., and Sarah L. Olson. 2000. "Symposium: Municipal Firearm Litigation: Ill Conceived from Any Angle," Connecticut Law Review, vol. 32, p. 1277.

McCaffrey, David P. 1982. OSHA and the Politics of Health Regulation. NY: Plenum Press.

Mintz, Morton. 1985. At any cost : corporate greed, women, and the Dalkon Shield. NY: Pantheon Books.

National Cancer Institute. 2003. SEER Cancer Statistics Review 1975-2000. (seer.cancer.gov/scr/1975-2000/results_single/sect_01-table.07.pdf)

Oster, Christopher. 2003. "MetLife Records Asbestos Charge Linked to Research." Wall Street Journal, Feb. 11, 2003, p. C.16.

Oster, Christopher. 2002. "Chubb, Hartford Take Asbestos Hits." Wall Street Journal, Oct. 31, 2002, p. A.6.

Parloff, Roger. 2002. “Asbestos: The $\$ 200$ Billion Miscarriage of Justice," Fortune, Monday, March 4, 2002.

Peto, J., A Decarli, et al. 1999. "The European mesothelioma epidemic," British Journal of Cancer, vol. 79, no. 3/4, pp. 666-672

Priest, George (1997), "Procedural versus Substantive Controls of Mass Tort Class Actions," J. of Legal Studies, vol. XXVI(2), Pt. 2, pp. 521-574.

Rheingold, Paul D. 1996. Mass Tort Litigation. Deerfield IL: CBC.

Rothstein, Paul F. 2000. "What Courts Can Do In the Face of the Never-Ending Asbestos Crisis," Mississippi Law Journal, vol. 71, pp. 1-34. 
Schuck, Peter H. 1986. Agent Orange on Trial: Mass Toxic Disasters in the Courts. Cambridge, MA: Harvard University Press.

Shavell, Steven. 1987. Economic Analysis of Accident Law. Cambridge, MA: Harvard University Press.

Sherrill, Robert. 1973. “Asbestos, the Saver of Lives, Has a Deadly Side," New York Times, Jan 21, 1973, p. 256.

Tidmarsh, Jay. 1998. Mass Tort Settlement Class Actions: Five Case Studies. Federal Judicial Center, Washington, DC.

Treaster, Joseph B., "Hartford to Pay \$1.5 Billion to Settle Asbestos Claims,"

New York Times, Dec 20, 2003, pg. C.4

Tweedale, Geoffrey. 2000. Magic Mineral to Killer Dust: Turned \& Newall and the Asbestos Hazard. Oxford University Press.

White, Michelle J. 1989. "The Corporate Bankruptcy Decision," Journal of Economic Perspectives, vol. 3, pp. 129-152.

White, Michelle J. 2002a. "Explaining the Flood of Asbestos Litigation: Consolidation, Bifurcation and Bouquet Trials," NBER w.p. 9362, December.

White, Michelle J. 2002b. "Why the Asbestos Genie Won't Stay in the Bankruptcy Bottle," University of Cincinnati Law Review, vol. 70:4, pp. 1319-1340. 